INDONESIAN JOURNAL OF

Clinical Pathology and Medical Laboratory

Majalah Patologi Klinik Indonesia dan Laboratorium Medik

\begin{tabular}{|c|c|c|c|c|c|}
\hline $\begin{array}{c}\text { IJCP \& ML } \\
\begin{array}{c}\text { (Maj. Pat. Klin. } \\
\text { Indonesia \& Lab. Med.) }\end{array}\end{array}$ & Vol. 17 & No. 3 & Hal. 127-177 & $\begin{array}{c}\text { Surabaya } \\
\text { Juli 2011 }\end{array}$ & $\begin{array}{c}\text { ISSN } \\
0854-4263\end{array}$ \\
\hline
\end{tabular}

Diterbitkan oleh Perhimpunan Dokter Spesialis Patologi Klinik Indonesia

Published by Indonesian Association of Clinical Pathologists

Terakreditasi No: 43/DIKTI/Kep/2008, Tanggal 8 Juli 2008 


\section{INDONESIAN JOURNAL OF \\ CLINICAL PATHOLOGY AND MEDICAL LABORATORY \\ Majalah Patologi Klinik Indonesia dan Laboratorium Medik}

\section{DAFTAR ISI}

\section{PENELITIAN}

Creatine Kinase Myocardial Band, Myeloperoxidase, Matrix Metalloproteinase- 9 dan Troponin T Pada IMA

(The Creatine Kinase Myocardial Band, Myeloperoxidase, Matrix Metalloproteinase-9 Activities and Troponin $T$ in Myocardial Infarction)

IA Hutagalung, I Patellongi, R Pakasi, M Arif, AA Mappahya, Hardjoeno

D-Dimer Penderita Sindrom Koroner Akut dan Stenosis

(D-Dimer in Acute Coronary Syndrome and Stenosis)

Birhasani, Lisyani BS, Ria T

Uji Hematologi Pasien Terduga Demam Berdarah Dengue Indikasi Rawat Inap

(Hematology Test of Dengue Hemorrhagic Fever on Suspected Patients Indicated for Hospitalization) Juranah, Darwati Muhadi, Mansyur Arif, Burhanuddin Bahar .

Imunokimiawi PGE2 Usus Ileum yang Kekurangan Energi Protein

(Immunohistochemistry of PGE2 Ileum Intestine Protein Energy Deficiency)

R. Heru Prasetyo

Gamma-glutamyltransferase dan Apolipoprotein B dengan Sindroma Metabolik

(Gamma-glutamyltransferase and Apolipoprotein B with the Metabolic Syndrome)

Tahono, M.I. Diah Pramudianti.

146-150

Umbi Ubi Jalar Ungu Bali (Ipomoea batatas) di Transaminase Serum, Malondialdehide Hepar dan Alkohol Kronis

(Balinese Purple Sweet Potato (Ipomoea batatas L) on SGOT, SGPT, MDA level and Chronic Alcohol) I Wayan Putu Sutirta-Yasa, I Made Jawi, Ida Bagus Ngurah, Anak Agung Ngurah Subawa.

Leukosit Infeksi Bakteri Sistemik

(Leucocyte in Systemic Bacterial Infections)

Meita Hendrianingtyas, MI. Tjahjati DM

Meningitis Tuberculosis

(Meningitis Tuberculosis)

Silvia Rachmayati, Ida Parwati, A Rizal, D Oktavia

Platelet Aggregation In Acute Coronary Syndrome

(Aggregasi Trombosit di Sindroma Koroner Akut)

Sulianty, Adi K Aman.

TELAAH PUSTAKA

Pemetaan Epitop dan Aplikasi Klinisnya

(Epitope Mapping and It's Clinical Aplication)

Jusak Nugraha.

LAPORAN KASUS

Infeksi Virus Rabies di Anak-anak

(Rabies Virus Infection in Children)

A.A.N. Subawa, DGD. Dharma Santhi, A.A Raka Sudewi, IWP. Sutirta Yasa 


\title{
GAMIMA-GLUTAMYLTRANSFERASE DAN APOLIPOPROTEIN B DENGAN SINDROMA METABOLIK
}

\author{
(Gamma-glutamyltransferase and Apolipoprotein B with the Metabolic Syndrome)
}

Tahono, M.I. Diah Pramudianti

\begin{abstract}
The number of Metabolic Syndrome (MS) patient has been rapidly increased. Diabetes Mellitus (DM) is a risk factor of coronary heart disease that increased four fold in the general population. Gamma-glutamyltransferase (GGT) is located on the external surface of most cells and mediates the uptake of glutathione, which is an important component of intracellular antioxidants defenses. The aims of this study was to analyze the correlation between GGT, Apolipoprotein B and metabolic syndrome parameters, a high sensitivity C-Reactive Protein (hs-CRP) as a marker of inflammation, and glutathione peroxidase (GPX) as an antioxidant marker in type 2 DM patients. This study used a cross sectional design. The subject of this study was type 2 DM patients who came to the Endocrinology Subdivision of Internal Medicine Department and Laboratory of Clinical Pathology at Dr. Moewardi Hospital Surakarta. To analyze this result, the researchers used Spearman ( $r$ ) correlation test with significance degree $p<0.05$ and confidence interval 95\%.The gammaglutamyltransferase serum showed a weak positive correlation with waist circumference $(r=0.18 ; p=0.045)$ and Apo B with fasting blood glucose ( $r=0.32 ; p=0.001)$; a mild positive correlation between Apo B and triglyceride $(r=0.45 ; p=0.001)$; a weak negative correlation between HDL cholesterol and GGT $(r=-0.22 ; p=0.020)$ and Apo $B(r=-0.20 ; p=0.027)$; a weak positive correlation between hs-CRP and GGT $(r=0.38 ; p=0.001)$, and Apo B $(r=0.18 ; p=0.042)$; and a weak negative correlation between Apo $B$ and GPx $(r=-0.22 ; p=0.019)$. Gamma-glutamyltransferase examination is superior to notice any inflammatory process than apoB $(r=0.38$ vs. $R=0.18)$, whereas apoB is superior as a predictor of inflammation than GGT $(r=-0.51$ vs. $R=-0,20)$. Gammaglutamyltransferase serum as an early marker of oxidative stress and Apo B was related to inflammation at the metabolic syndrome and diabetes. Measurement of GGT serum is reliable, easy, and not expensive, it might have important implications both clinically and epidemiologically.
\end{abstract}

Key words: GGT, apo B, metabolic syndrome

\begin{abstract}
ABSTRAK
Jumlah penderita sindroma metabolik (SM) dari tahun ke tahun menunjukkan peningkatan. Diabetes Melitus (DM) merupakan salah satu penyebab penyakit jantung koroner. Penyebab penyakit peredaran darah jantung (kardiovaskuler) di penderita DM tipe 2 meningkat empat kali lipat dibandingkan dengan populasi umum. Gamma-glutamyltransferase (GGT) terletak di permukaan luar sebagian besar sel, yang berfungsi utama menjaga kepekatan dalam sel gluthatione (GSH), yaitu komponen penting pertahanan antioksidan sel tertentu. Tujuan penelitian ini untuk mengetahui kenasaban antara kadar GGT dan Apoliporotein B serta tolok ukur sindroma metabolik, high sensitivity C-Reactive Protein (hs-CRP) sebagai petanda (marker) inflamasi, dan GPx sebagai petanda status antioksidan di pengidap DM tipe 2. Penelitian ini menggunakan rancangan penelitian potong lintang. Subjek penelitian adalah pasien DM tipe 2 yang memeriksakan diri di Poliklinik Penyakit Dalam sub bagian Endokrinologi dan memeriksakan darah di Laboratorium Patologi Klinik RSUD Dr. Moewardi (PK RSDM) Surakarta. Analisis statistiknya menggunakan uji kenasaban Spearman (r), p bermakna apabila < 0,05 dengan selang kepercayaan 95\%. Kenasaban positif lemah didapatkan bermakna antara kadar GGT dan tolok ukur SM meliputi lingkar pinggang $(r=0,18, p=0,045)$, Apo B dengan GDP $(r=0,32, p=0,001)$, kenasaban positif sedang bermakna antara Apo B dan trigliserida $(r=-0,45, p=0,001)$. Kenasaban negatif lemah bermakna antara kolesterol HDL dan GGT $(r=-0,22, p=0,020)$ dan Apo B $(r=-0,20, p=0,027)$. Kenasaban positif lemah bermakna antara hs-CRP dan GGT $(r=0,38, p=0,001)$, dan Apo B $(r=0,18, p=0,042)$. Kenasaban negatif lemah bermakna antara Apo B dan GPx $(r=-0,22$, $\mathrm{p}=0$,019). Pemeriksaan GGT lebih unggul untuk melihat inflamasi dibandingkan dengan ApoB $(r=0,38 v s . r=0,18)$, sedangkan ApoB lebih unggul sebagai peramal (prediktor) terjadinya inflamasi dibandingkan dengan GGT $(r=-0,51$ vs. $r=-0,20)$. Serum GGT sebagai petanda awal tegasan (stres) oksidatif dan ApoB berhubungan dengan inflamasi yang terjadi di penderita sindroma metabolik dan diabetes. Hal ini berpengaruh penting baik secara klinik maupun epidemiologik, sebab pemeriksaan GGT mudah, murah dan dapat dilakukan sebagai kebiasaan sehari-hari di laboratorium.
\end{abstract}

Kata kunci: GGT, apo B, sindroma metabolik

\section{PENDAHULUAN}

Jumlah penderita Sindroma Metabolik (SM) dari tahun ke tahun mengalami peningkatan. World Health Organization (WHO) meramalkan kenaikan jumlah pasien dari 8,4 juta (tahun 2000) menjadi 21,3 juta (tahun 2030). Berdasarkan data Badan Pusat Statistik Indonesia tahun 2003 jumlah penduduk usia lebih dari 20 tahun sebesar 133 juta jiwa, sedangkan jumlah pasien Diabetes Melitus (DM) di 
daerah perkotaan sebesar $8,2 \%$ dan $5,5 \%$ di daerah pedesaan. ${ }^{1}$

Diabetes Melitus merupakan salah satu kebahayaan penyakit jantung koroner (PJK), jumlah penyakit tertentu di dunia terus meningkat. Kebahayaan penyakit kardiovaskuler yang terjadi di penderita DM tipe 2 meningkat empat kali lipat dibandingkan dengan populasi umum. ${ }^{2}$

Sindroma metabolik atau sindroma dismetabolik kardiovaskuler atau sindroma resistensi insulin merupakan sekumpulan faktor kebahayaan akibat gangguan metabolik. Hasil telitian menunjukkan bahwa SM merupakan keadaan proinflamasi dengan adanya peningkatan kepekaan (high sensitivity) terhadap C-Reactive Protein (hs-CRP). Tiga patokan diagnosis SM yang banyak digunakan yaitu WHO 1999, The National Cholesterol Education Program Adult Treatment Panel (NCEP ATP) III 2005 dan International Diabetes Federation (IDF) 2005. Ketiganya bertolok ukur utama yang sama, tetapi penentuan patokan berbeda, meliputi kegemukan, dislipidemia, kadar glukosa tinggi (hiperglikemia) dan tekanan darah tinggi. 3,4

Patokan NCEP ATP III ubahsuaian (modifikasi) Asia menggunakan tolok ukur lebih mudah diperiksa dan diterapkan dibandingkan dengan tolok ukur patokan WHO. Ditetapkan SM apabila didapatkan 3 (tiga) dari 5 (lima) tolok ukur SM yang meliputi kegemukan daerah perut/obesitas abdominal (lingkar pinggang laki-laki $\geq 90 \mathrm{~cm}$, perempuan $\geq 80 \mathrm{~cm}$ ), tekanan darah $\geq 130 / 85 \mathrm{mmHg}$ atau mendapat pengobatan anti tekanan darah tinggi, glukosa darah puasa $(\mathrm{GDP}) \geq 100 \mathrm{mg} / \mathrm{dL}$ atau mendapat pengobatan anti hiperglikemia, trigliserida $\geq 150 \mathrm{mg}$ / dL, serta kolesterol HDL $<40 \mathrm{mg} / \mathrm{dL}$ untuk laki-laki dan $<50 \mathrm{mg} / \mathrm{dL}$ untuk perempuan atau mendapat pengobatan dislipidemia. Penelitian, epidemiologik dan bentuk genetik hiperkolesterolemia menunjukkan peningkatan kolesterol sebagai sasaran pengobatan dan pencegahan utama penyakit kardiovaskuler. ${ }^{4,5}$

Gamma-glutamyltransferase (GGT) merupakan enzim glikoprotein heterodimerik yang mengkatalisasi secara pengalihan berbalik (reversibel transfer) kelompok glutamyl, yaitu dari glutamyl-peptide dan asam amino menjadi peptida serta glutamyl.6,7 Enzim GGT sebagian besar berasal dari hati yang terletak di permukaan luar sebagian besar sel. Fungsi utamanya ialah menjaga kepekatan dalam sel gluthatione (GSH), tolok ukur penting pertahanan antioksidan sel tertentu. Selama ini GGT dikenal sebagai petanda penyakit hati, peminum alkohol, steatosis alkohol dan resistensi insulin hepatik pada DM tipe 2.6,7

C-Reactive Protein (CRP) merupakan plasma protein yang dihasilkan hati dan berperan pada inflamasi. Pembentukan plak aterosklerosis pada tahap awal stimulasi CRP melalui peningkatan pengeluaran bahan pelekat (ekspresi adhesin) molekul sel endotel, pembuatan kemoatraktan kemokin dan pengambilan LDL oleh makrofag, robeknya plak aterosklerosis melalui peningkatan Plasminogen Activator Inhibitor type 1 (PAI-1), dan penurunan Nitric Oxide (NO). 6,8

Glutathione peroxidase (GPx) adalah enzim anti oksidan untuk menawar racun (detoksifikasi) lipid peroksida, hidrogen peroksida $\left(\mathrm{H}_{2} \mathrm{O}_{2}\right)$ dan melenyapkan ROS. Kekurangan ensim GPx menyebabkan peningkatan ROS, penurunan kemampuan hayati (bioavibilitas) NO, disfungsi endotel dan aterosklerosis di pengidap DM. ${ }^{9,10}$

Apolipoprotein merupakan komponen protein dari lipoprotein, terdiri atas A-I, A-II, A-IV, B-100, B-48, C-I, C-II, C-III, E, dan (a). Apolipoptotein B (Apo B) adalah protein susunan utama unsur aterogenik. Pemeriksaan Apo B berguna untuk pasien hipertrigliseridemia DM tipe 2, dan mengembalikan unsur LDL sebagai sasaran serangan NCEP ATP III. Apolipoprotein B merupakan petanda yang lebih pasti untuk pemantauan pengobatan statin dibandingkan dengan LDL atau non HDL kolesterol. Small dense LDL yaitu LDL pemadatan lebih kecil, yang berbahaya, dapat dihitung dari angka banding LDL lansung dan Apo B, apabila kurang dari 1,2 akan meningkatkan kebahayaan PJK tiga kali lipat dibandingkan dengan LDL ukuran normal. ${ }^{11,12}$

Diabetes melitus masih menunjukkan peningkatan angka kejadian dan jumlah penyakit tertentu di seluruh dunia, di pengidap DM terjadi stres oksidatif yang memacu munculnya komplikasi DM. Hubungan GGT dengan kebahayaan kardiovaskuler belum jelas. GGT diketahui berhubungan dengan stres oksidatif dan inflamasi di pengidap SM dan DM. Pemeriksaan petanda stres oksidatif secara langsung merupakan pemeriksaan yang mahal, rumit dan tidak dapat dilaksanakan rutin di laboratorium. GGT sebagai penanda stres oksidatif merupakan pemeriksaan yang mudah, murah, cepat, dan dapat dilakukan sebagai kebiasaan sehari-hari di laboratorium, tetapi belum dimanfaatkan dengan baik oleh para peklinik.

Oleh karena itu di dalam kajian ini para peneliti ingin mengetahui kenasaban antara kadar GGT dan Apo B dengan tolok ukur SM, kadar GGT dan Apo B dengan kadar hs-CRP sebagai penanda inflamasi serta kadar GGT dan Apo B dengan kadar GPx sebagai petanda status anti oksidan di penderita DM tipe 2.

\section{METODE}

Penelitian ini menggunakan rancangan cross sectional. Pemilihan subjek secara konsekutif (berurutan). Pasien berobat di Poliklinik Penyakit Dalam di sub bagian Endokrinologi RSUD dr Moewardi (RSDM) Surakarta dan memeriksakan darah di Laboratorium Patologi Klinik RSDM 
Surakarta. Selama bulan Juni-Juli 2010 didapatkan subjek yang memenuhi patokan kesertaan dan tidak disertakan sejumlah 91 orang.

Patokan kesertaan meliputi pasien DM tipe 2, usia $\geq 40$ tahun dan $\leq 60$ tahun, menyetujui dan menandatangani surat persetujuan tindakan. Patokan tidak disertakan meliputi riwayat atau sedang menderita penyakit hati (liver), ditandai peningkatan 3 (tiga) kali di atas harga rujukan untuk SGOT $\left(\sigma^{*}>\right.$ $105 \mathrm{IU} / \mathrm{L}$, q $>93 \mathrm{IU} / \mathrm{L})$, SGPT $\left(0^{\pi}>135 \mathrm{IU} / \mathrm{L}\right.$, + > > $102 \mathrm{IU} / \mathrm{L})$ atau GGT $\left({ }^{\star}>165 \mathrm{IU} / \mathrm{L}\right.$, , $\left.>114 \mathrm{IU} / \mathrm{L}\right),{ }^{13}$ keadaan infeksi atau inflamasi ditandai dengan kadar $\mathrm{CRP} \geq 10 \mathrm{mg} / \mathrm{L}$ atau jumlah keseluruhan lekosit $>$ $11 \times 10^{3} \mathrm{uL}$, sedang minum obat antiinflamasi atau antioksidan, dan riwayat minum alkohol.

Pemeriksaan laboratorik didahului uji ketelitian dan ketepatan analitik, sehingga mutu hasil periksaan dapat dipertanggungjawabkan. Data karakteristik subjek dalam bentuk rerata dan simpangan baku bila persyaratannya terpenuhi. Untuk mengetahui derajat kekuatan hubungan dua variabel digunakan kenasaban Spearman (r) apabila data tidak tersebar secara normal. Analisis statistik diolah menggunakan program komputer, $\mathrm{p}$ bermakna apabila $<0,05$ dan selang kepercayaan $95 \%$.

\section{HASIL DAN PEMBAHASAN}

Hasil uji ketelitian sehari dan hari ke hari tolok ukur GGT, GDP, kolesterol HDL, trigliserida, hs-CRP dan GPx adalah baik dan menunjukkan ketelitian pemeriksaan yang menetap dari waktu ke waktu. Ciri dasar subjek penelitian (tabel 1) didapatkan kelompok median yang berusia $56 \pm$ 5,1 tahun, terdiri atas 34 laki-laki (37,4\%) dan 57 perempuan $(62,6 \%)$. Jumlah pasien SM 71 orang (78\%) dan $66,2 \%$ diantaranya adalah perempuan. Subjek dengan kegemukan 49,5\% (45 orang) dan berlebihan berat badan (overweight) sebanyak $28,6 \%$ (26 orang). Perseorangan yang kegemukan dan berlebihan berat badan akan meningkatkan kebahayaan DM tipe 2 dan penyakit kardiovaskuler Alberti et al. ${ }^{4}$ Lama pengidapan DM yang berkisar $5 \pm$ 7,7 tahun, dan median HbA1c 7,7 $\pm 2,6 \%$ termasuk berpatokan pengendalian DM yang sedang.

Berdasarkan patokan NCEP ATP III 2005 SM didiagnosis jika memiliki tiga atau lebih tolok ukur. Pada penelitian ini dari 91 pasien DM tipe 2 didapatkan 37 subjek (52\%) memiliki 3 (tiga) tolok ukur SM, 26 (36\%) memiliki 4 (empat) tolok ukur SM dan 8 (11\%) memiliki 5 (lima) tolok ukur SM.

Semakin lama subjek menderita DM $(16,0 \pm 17,7$ tahun), semakin banyak jumlah tolok ukur SM yang dimiliki yaitu 5 (lima) tolok ukur. Semakin tinggi kadar GGT $(58,3 \pm 49,1 \mathrm{IU} / \mathrm{L})$, Apo B $(123,4 \pm$ 20,1), hs-CRP (4,4 $\pm 1,1 \mathrm{mg} / \mathrm{L})$ dan HbA1c $(9,0 \pm$
2,2\%), maka semakin banyak pula jumlah tolok ukur SM yang dimiliki (lima tolok ukur).

Semakin kecil, padat dan berbahaya LDL tertentu $(1,2 \pm 0,2)$ maka semakin banyak jumlah tolok ukur SM yang dimiliki (lihat Tabel 2).

Tabel 1. Karakteristik dasar subjek penelitian

\begin{tabular}{|c|c|c|}
\hline Variabel & $\begin{array}{c}\text { Median } \\
\pm \text { SB (SD) }\end{array}$ & Jumlah (\%) \\
\hline Umur (tahun) & $56 \pm 5,1$ & \\
\hline \multicolumn{3}{|l|}{ Jenis kelamin $(\mathrm{L} / \mathrm{P})$} \\
\hline Laki-laki & & $34(37,4 \%)$ \\
\hline Perempuan & & $57(62,6 \%)$ \\
\hline \multicolumn{3}{|l|}{ Indeks massa) tubuh $\left(\mathrm{kg} / \mathrm{m}^{2}\right)$} \\
\hline $\begin{array}{l}\text { Berat badan kurang } \\
\text { (Underweight) }\end{array}$ & $17,5 \pm 1,0$ & $4(4,4 \%)$ \\
\hline Normal & $21,5 \pm 1,2$ & $16(17,6 \%)$ \\
\hline Berat badan berlebihan & $23,5 \pm 0,5$ & $26(28,6 \%)$ \\
\hline Kegemukan & $27,0 \pm 2,6$ & $45(49,5 \%)$ \\
\hline Kadar HbA1c (\%) & $7,7 \pm 2,6$ & \\
\hline Kadar GGT (IU/L) & $29,7 \pm 28,9$ & \\
\hline Kadar Apo B (mg/dL) & $103,0 \pm 27,7$ & \\
\hline Kadar small dense-LDL & $1,4 \pm 0,3$ & \\
\hline Lingkar pinggang $(\mathrm{cm})$ & $91,0 \pm 10,1$ & \\
\hline \multicolumn{3}{|l|}{ Kegemukan daerah perut } \\
\hline Normal & & $25(27,5 \%)$ \\
\hline Kegemukan daerah perut & & $66(72,5 \%)$ \\
\hline $\begin{array}{l}\text { Kadar glukosa darah puasa } \\
\text { (mg/dL) }\end{array}$ & $142 \pm 67,9$ & \\
\hline $\begin{array}{l}\text { Kadar kolesterol HDL } \\
\text { (mg/dL) }\end{array}$ & $49 \pm 13,0$ & \\
\hline Kadar trigliserida $(\mathrm{mg} / \mathrm{dL})$ & $139 \pm 90,0$ & \\
\hline $\begin{array}{l}\text { Tekanan darah sistolik } \\
(\mathrm{mmHg})\end{array}$ & $130 \pm 23,1$ & \\
\hline $\begin{array}{l}\text { Tekanan darah diastolik } \\
(\mathrm{mmHg})\end{array}$ & $80 \pm 13,5$ & \\
\hline Kadar hs-CRP (mg/L) & $2,5 \pm 2,7$ & \\
\hline Kadar GPx (U/L) & $6831 \pm 2660$ & \\
\hline \multicolumn{3}{|l|}{ Sindroma metabolik } \\
\hline $\mathrm{Ya}$ & & $71(78 \%)$ \\
\hline Tidak & & $20(22 \%)$ \\
\hline $\begin{array}{l}\text { Lama pengidapan DM } \\
\text { (tahun) }\end{array}$ & $5 \pm 7,7$ & \\
\hline \multicolumn{3}{|l|}{ Status) merokok } \\
\hline Tidak pernah merokok & & $70(76,9 \%)$ \\
\hline $\begin{array}{l}\text { Riwayat perokok }>10 \\
\text { tahun yang lalu }\end{array}$ & & $6(6,6 \%)$ \\
\hline $\begin{array}{l}\text { Riwayat perokok } \leq 10 \\
\text { tahun yang lalu }\end{array}$ & & $4(4,4 \%)$ \\
\hline $\begin{array}{l}\text { Sekarang masih merokok } \\
\text { Jumlah batang rokok } \\
\text { perhari }\end{array}$ & $2 \pm 0,3$ & $11(12,1)$ \\
\hline \multicolumn{3}{|l|}{ Kegiatan fisik } \\
\hline Tidak berkegiatan & & $22(24,2 \%)$ \\
\hline Ringan & & $65(71,4 \%)$ \\
\hline Berat & & $4(4,4 \%)$ \\
\hline
\end{tabular}


Tabel 2. Perbandingan tolok ukur pemeriksaan berdasarkan jumlah tolok ukur SM

\begin{tabular}{|c|c|c|c|c|c|}
\hline \multirow{2}{*}{$\begin{array}{c}\text { Tolok ulkur } \\
\text { pemeriksaan }\end{array}$} & \multicolumn{3}{|c|}{ Jumlah tolok ukur SM [Rerata \pm SD] } & $f$ & $\mathbf{p}$ \\
\hline & 3 & 4 & 5- & \multicolumn{2}{|c|}{ (1 way Anova) } \\
\hline Umur (tahun) & $54,92 \pm 5,60$ & $56,58 \pm 3,87$ & $55,59 \pm 4,57$ & 0,9 & 0,425 \\
\hline Lama DM (tahun) & $4,57 \pm 3,91$ & $6,55 \pm 6,16$ & $16,00 \pm 17,73$ & 7,9 & $0,001^{\dagger}$ \\
\hline IMT $\left(\mathrm{kg} / \mathrm{m}^{2}\right)$ & $25,49 \pm 3,79$ & $26,15 \pm 3,12$ & $26,38 \pm 4,24$ & 0,4 & 0,697 \\
\hline HbA1c (\%) & $7,76 \pm 2,11$ & $8,47 \pm 2,80$ & $9,00 \pm 2,15$ & 1,2 & 0,298 \\
\hline Apo B (mg/dL) & $102,43 \pm 27,95$ & $111,65 \pm 31,39$ & $123,38 \pm 20,11$ & 2,0 & 0,134 \\
\hline small dense LDL & $1,37 \pm 0,30$ & $1,24 \pm 0,32$ & $1,17 \pm 0,20$ & 2,2 & 0,118 \\
\hline GGT (IU/L) & $40,35 \pm 29,90$ & $45,15 \pm 26,47$ & $58,25 \pm 49,10$ & 1,1 & 0,339 \\
\hline hs-CRP (mg/L) & $3,18 \pm 2,81$ & $3,62 \pm 2,84$ & $4,44 \pm 1,13$ & 0,8 & 0,464 \\
\hline GPx (U/L) & $6875 \pm 2947$ & $7079 \pm 2256$ & $7125 \pm 2827$ & 0,1 & 0,945 \\
\hline
\end{tabular}

Tabel 3. Kenasaban kadar GGT dan tolok ukur SM dengan variabel penelitian lain

\begin{tabular}{|c|c|c|c|c|}
\hline \multirow{2}{*}{ Variabel } & \multirow{2}{*}{\multicolumn{2}{|c|}{$\begin{array}{c}\text { GGT } \\
\mathbf{r}(\text { Spearman p) }\end{array}$}} & \multicolumn{2}{|c|}{ Apo B } \\
\hline & & & $\mathbf{r}\left(S_{1}\right.$ & n p) \\
\hline \multicolumn{5}{|l|}{ Tolok ukur sindroma metabolik } \\
\hline Lingkar pinggang $(\mathrm{cm})$ & 0,18 & $0,045^{\dagger}$ & 0,14 & 0,095 \\
\hline Kadar GDP (mg/dL) & $-0,02$ & 0,430 & 0,32 & $0,001^{\dagger}$ \\
\hline Kadar kol. HDL (mg/dL) & $-0,22$ & $0,020^{\dagger}$ & $-0,20$ & 0,027 \\
\hline Kadar trigliserida (mg/dL) & 0,15 & 0,077 & 0,45 & $0,001^{\dagger}$ \\
\hline TD sistolik (mmHg) & 0,02 & 0,425 & 0,08 & 0,239 \\
\hline TD diastolik (mmHg) & 0,05 & 0,321 & 0,17 & 0,052 \\
\hline (Small dense) LDL & $-0,20$ & $0,031^{\dagger}$ & $-0,51$ & $0,001^{\dagger}$ \\
\hline Kadar hs-CRP (mg/L) & 0,38 & $0,001^{\dagger}$ & 0,18 & $0,042^{\dagger}$ \\
\hline Kadar GPx (U/L) & $-0,02$ & 0,438 & $-0,22$ & 0,019 \\
\hline
\end{tabular}

$\dagger=\mathrm{p}<0.005$

Kenasaban positif lemah didapatkan antara GGT dan tolok ukur SM (Tabel 3) meliputi lingkar pinggang $(\mathrm{r}=0,18 ; \mathrm{p}=0,045)$, hal ini sesuai penelitian André yang didasari Data From the Epidemiological Study on the Insulin Resistance Syndrome (DESIR) Cohort yang mendapatkan kenasaban antara GGT dan lingkar pinggang (laki-laki $r=0,29$, perempuan $r=$ $0,20) \cdot 14$

Kenasaban positif lemah didapatkan bermakna antara Apo B dan GDP ( $\mathrm{r}=0,32 ; \mathrm{p}=0,001)$, tetapi tidak didapatkan kenasaban antara GGT dan GDP $(r=-0,08 ; p=0,264)$. Kemungkinan hal ini disebabkan subjek penelitian yang menggunakan obat antidiabetik. Sekitar 50\% dari subjek penelitian ini menggunakan obat antidiabetik metformin. Metformin mampu meningkatkan penggunaan glukosa baik itu di otot maupun di daerah usus (intestinal), sehingga dapat menurunkan kadar GDP sebesar $20 \%$.

Kenasaban positif sedang didapatkan bermakna antara Apo B dan trigliserida $(r=0,45 ; p=0,001)$, tetapi tidak didapatkan kenasaban antara GGT dan trigliserida $(r=0,15 ; p=0,077)$. Hal ini tidak sesuai dengan penelitian DESIR Cohort yang mendapatkan kenasaban antara GGT dan trigliserida (laki-laki $\mathrm{r}=$ $0,29$, perempuan $r=0,20) \cdot{ }^{14}$
Berdasarkan uji kenasaban Spearman didapatkan hasil kenasaban negatif lemah bermakna antara tolok ukur SM lain yaitu kolesterol HDL dengan GGT $(r=$ $-0,22 ; \mathrm{p}=0,020)$ dan Apo B ( $r=-0,20 ; \mathrm{p}=0,027)$. kenasaban negatif lemah bermakna antara GGT dan sd-LDL $(r=-0,20 ; p=0,031)$, dan kenasaban negatif sedang bermakna antara Apo B dan sd-LDL $(r=-0,51$; $\mathrm{p}=0,001$ ). Didapatkan juga kenasaban positif lemah bermakna antara GGT dan hs-CRP $(r=0,38 ; \mathrm{p}=$ 0,001), dan antara Apo B dan hs-CRP ( $\mathrm{r}=0,18$; $\mathrm{p}$ $=0,042)$. Penelitian Lee \& Jacobs di 12.110 subjek asal the third U.S. National Health and Nutrition Examination Survey (NHANES III) secara potong lintang didapatkan kadar serum GGT, bahkan di kadar normal berhubungan positif dengan kadar CRP. ${ }^{15}$

Penelitian kenasaban antara GGT dan GPx masih jarang dilakukan. Aktivitas dan pengeluaran enzim GPx dipengaruhi oleh faktor di dalam (usia, jenis kelamin, endokrin), di luar (lingkungan, nutrisi) dan keragaman genetika. ${ }^{9,16}$ Kenasaban negatif didapatkan lemah bermakna antara Apo B dan GPx $(\mathrm{r}=-0,22 ; \mathrm{p}=0,019)$, tetapi tidak didapatkan kenasaban antara GGT dengan GPx $(r=-0,02$; $p=0,438)$. Kemungkinan hal tersebut karena tidak dianalisis secara lebih dalam terhadap faktor di dalam, di luar maupun keragaman genetika yang 
dapat mempengaruhi aktivitas dan ekspresi ensim GPx. Di samping kemungkinan lainnya adalah jumlah sampel yang sedikit, sehingga perlu dilakukan penelitian lanjutan dengan jumlah sampel lebih besar agar diketahui peran GGT yang lebih mendalam terhadap aktivitas ensim GPx.

Pemeriksaan hs-CRP merupakan penanda adanya inflamasi. Yaitu kenasaban positif lemah terdapat bermakna antara GGT dan hs-CRP ( $\mathrm{r}=0,38$; $\mathrm{p}=$ 0,001), dan antara Apo B dan hs-CRP ( $\mathrm{r}=0,18$; $\mathrm{p}=$ 0,042). Pemeriksaan GGT lebih unggul untuk melihat adanya inflamasi dibandingkan dengan ApoB ( $\mathrm{r}=$ $0,38$ vs. $r=0,18)$.

Pemeriksaan sd-LDL sebagai peramal terjadinya inflamasi. Kenasaban negatif lemah terdapat bermakna antara kadar GGT dan sd-LDL ( $r=-0,20$; $\mathrm{p}=0,031$ ), dan kenasaban negatif sedang terdapat bermakna antara Apo B dan sd-LDL $(r=-0,51$; $\mathrm{p}=0,001)$. Pemeriksaan ApoB lebih unggul sebagai peramal terjadinya inflamasi dibandingkan dengan GGT ( $r=-0,51$ vs. $r=-0,20)$.

\section{SIMPULAN DAN SARAN}

Serum GGT sebagai penanda awal stres oksidatif dan Apo B berhubungan dengan inflamasi yang terjadi di pasien SM dan DM. Hal ini berpengaruh penting baik secara klinik maupun epidemiologik, sebab pemeriksaan GGT mudah, murah dan dapat dilakukan menurut kebiasaan sehari-hari di laboratorium. Perlu diteliti lebih lanjut untuk menilai hubungan GGT dengan petanda stres oksidatif secara langsung, Apo B dengan petanda inflamasi lain serta bebas (independent) dari hs-CRP dan beragam atau petanda hayati (biomarker) lainnya untuk meramal faktor kebahayaan terkait kardiovaskuler, dengan rancangan penelitian yang berbeda di berbagai jenis populasi serta jumlah sampel yang lebih banyak. Untuk melihat inflamasi, pemeriksaan GGT lebih dianjurkan daripada terkait Apo B; sedangkan ApoB lebih dianjurkan sebagai peramal terjadinya inflamasi daripada dengan GGT.

\section{DAFTAR PUSTAKA}

1. Perkeni. Konsensus Pengelolaan dan Pencegahan Diabetes Melitus Tipe 2 di Indonesia, Jakarta, 2006; 1-8.

2. Johnstone MT \& Nesto R. Diabetes Melitus and Heart Disease. In: Khan CR, Weir GC, Ing GL, Jacobson AM, Moses AC, \& Smith RJ (Eds.), Joslin's Diabetes Melitus, Boston, Lippincott William \& Wilkins, 2005; 977.

3. Deedwania PC. Metabolic Syndrome and Vascular Disease, is Nature or Nature Leading the New Epidemic of Cardiovascular Disease? Circulation, 2004; (109): 2-4.

4. Alberti KG, Zimmet P, \& Shaw J. The Metabolic Syndrome a New Worldwide Definition, Lancet, 2005; 366(9491): 1059-1062.

5. NCEP ATP III. Executive Summary of The Third Report of the National Cholesterol Education Program (NCEP) Expert Panel on Detection, Evaluation, and Treatment of High Blood Cholesterol in Adults (Adult Treatment Panel III), JAMA, 2001; 285(19): 2486-2497.

6. Sies H \& Packer L. Methods in Enzymology, Elsevier Inc, 2005; 484-498.

7. Rodés J, Benhamou JP, Blei AT, Reichen J, \& Rizzetto M. Textbook of Hepatology: from Basic Science to Clinical Practice, $3^{\text {rd }}$ Ed, Blackwell Publishing Ltd, 2007; 312-325.

8. Cefalu WT, \& Cannon CP. Atlas of Cardiometabolic Risk, Informa Healthcare Inc, USA, 2007; 13-167.

9. Me'zes M, Erdelyl M, Shaaban G, Virag G, Balogh K, \& Weber M. Genetics of Glutathione Peroxidase, Acta Biol Szeged, 2003; 47(1-4): 135-138.

10. Stocker R, \& Keaney JF. Role of Oxidative Modifications in Atherosclerosis, Physiological Reviews, 2004; 84: 1381-1478.

11. Wagner AM, Perez A, Zapico E, Ordonez-llanos J. Non-HDL Cholesterol and Apolipoprotein B in the Dyslipidemic Classification of Type 2 Diabetic Patients, Diabetes Care, 2003; 26: 2048-2051.

12. Charlton-Menys V, Betteridge DJ, Colhoun H, Fuller J, France M, Hitman GA, et al. Targets of Statin Therapy: LDL Cholesterol, Non-HDL Cholesterol, and Apolipoprotein B in Type 2 Diabetes in the Collaborative Atorvastatin Diabetes Study (CARDS), Clinical Chemistry, 2009; (55)3: 473-480.

13. Iqbal A, Khoja A, Iftikhar U, \& Mehjabeen. A Comparison of The Effects of Gamma Glutamyltransferase on Age and Obesity Among Normal, Hypertensive and Type 2 Diabetics, Biomedica, 2009; 25 (Jul.-Dec): 123-127.

14. André P, Balkau B, Vol S, Charles MA, \& Eschwège E. $\gamma$ Glutamyltransferase Activity and Development of the Metabolic Syndrome (International Diabetes Federation Definition) in Middle-Aged Men and Women, Data From the Epidemiological Study on the Insulin Resistance Syndrome (DESIR) Cohort, Diabetes Care, 2007; 30: 2355-2361.

15. Lee DH, \& Jacobs DR Jr. Association between Serum Gammaglutamylransferase and C-Reactive Protein, Atherosclerosis, 2005; 178: 327-330.

16. Leopold JA, \& Loscalzo J. Oxidative Enzymopathies and Vascular Disease, Arterioscler Thromb Vasc Biol, 2005; 25: 1332-1340. 